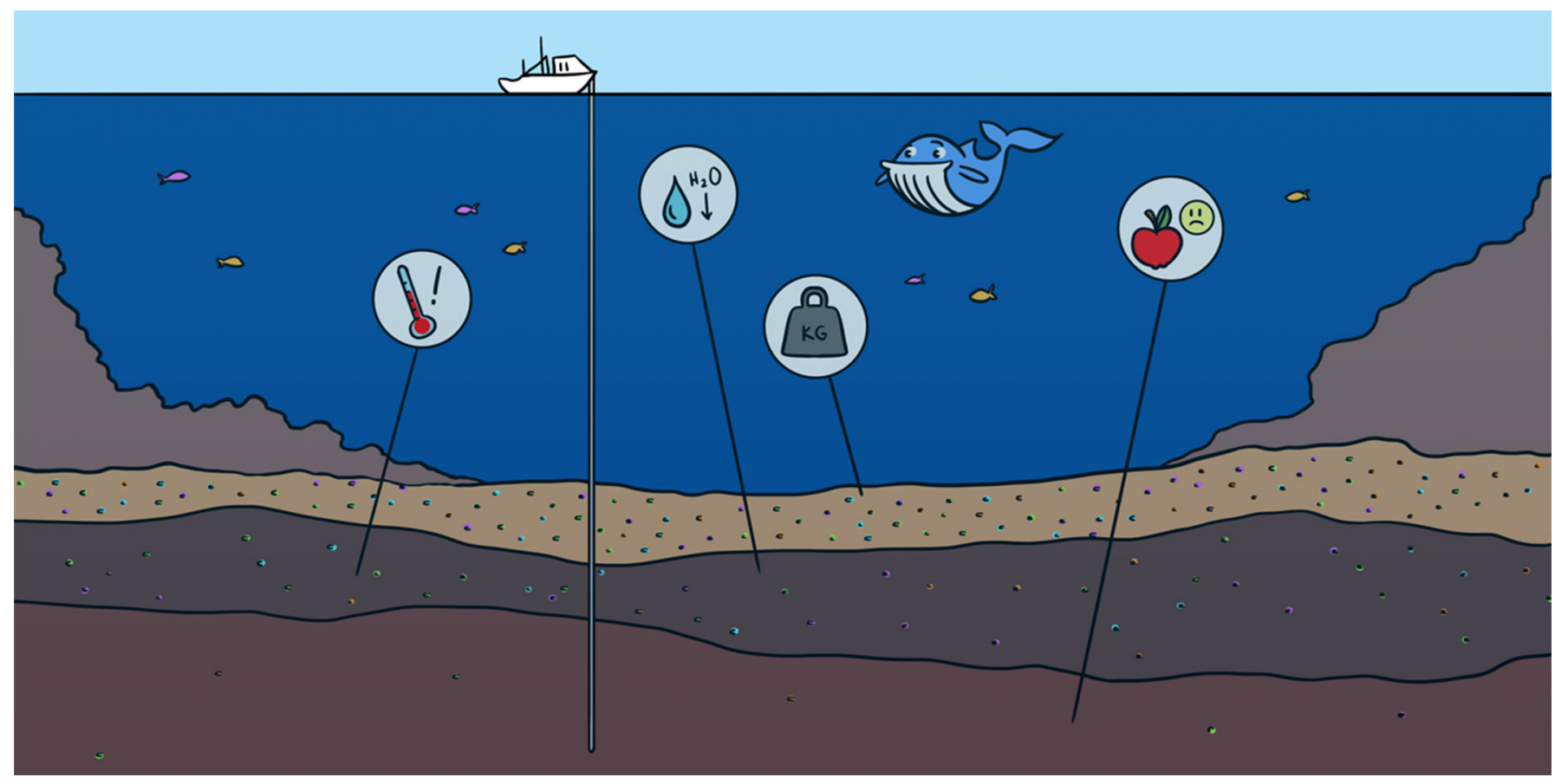

\title{
MICROBIAL LIFE DEEP UNDER THE SEAFLOOR-A STORY OF NOT GIVING UP
}

\section{Man-Yin Tsang ${ }^{1 *}$ and Fumio Inagaki ${ }^{2}$}

${ }^{1}$ Geobiology Isotope Laboratory, Department of Earth Sciences, University of Toronto, Toronto, ON, Canada

${ }^{2}$ Mantle Drilling Promotion Office, Institute for Marine-Earth Exploration and Engineering (MarE3), Japan Agency for Marine-Earth Science and Technology (JAMSTEC), Yokohama, Japan

YOUNG REVIEWER:

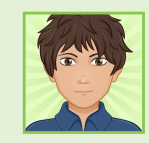

NICOLAS

AGE: 9

\section{SEDIMENT}

Soft, solid materials that settle at the bottom of a water body. Examples include sand and clay.
Below the seafloor are trillions of single-celled microbial life. Marine sediments bury these microorganisms deeper and deeper. Meanwhile, the microorganisms face increasing pressures and temperatures and reduced amounts of food and water. Although they are living in difficult conditions, these microorganisms stay alive and maintain their communities. To date, we know that these microbial communities can survive for millions of years, at $2.5 \mathrm{~km}$ below the seafloor, and at temperatures over $100^{\circ} \mathrm{C}$. Scientists use multiple approaches to study these fascinating microorganisms.

\section{UNDER THE SEAFLOOR: A HARSH PLACE TO LIVE}

You jump into the sea and sink slowly in the salty water. It gets darker and darker, as light cannot reach the deep sea. You lie on the seafloor with some fish, squids, and worms. At a rate $<1 \mathrm{~cm}$ every 1,000 years, dust from above buries you. You become part of the sediment and can hardly move. How can one survive under the seafloor? While 


\section{Figure 1}

Many microorganisms, shown here as colored circles and ovals, live under the seafloor. Living conditions are more difficult with increasing sediment depth and age, because temperature and pressure increase. Scientists drill into the seafloor from a research vessel to study these microorganisms and environments.

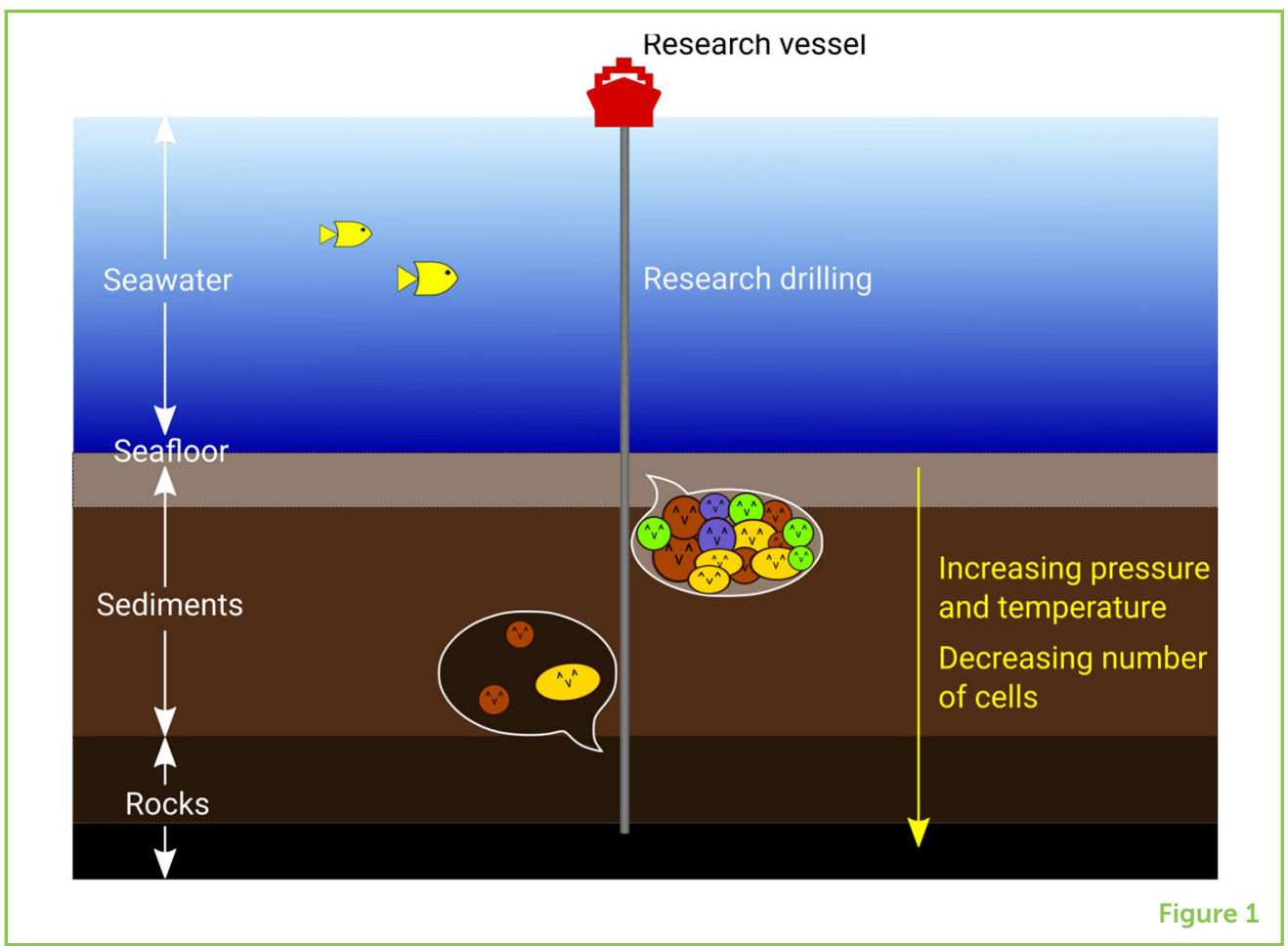

humans are not fit to live there, microorganisms are (Figure 1). You can find them in the sediment of all the seafloors on Earth. These microorganisms are so tiny that each of them is made of only one cell. Scientists estimate that there are more one-celled organisms under the seafloor than there are stars in the universe [1]!

Is it difficult for the microorganisms to live under the seafloor? Yes, it is. These organisms face high pressures, lack of water and food, and high temperatures.

Seafloor microorganisms need to cope with higher pressures the deeper they are buried. In deep-sea sediments, these microorganisms withstand pressures hundreds of times higher than what we experience at the surface of the Earth (Figure 2a). Therefore, scientists study these microorganisms to understand the limits of life [2] and the strategies these microorganisms use for survival. These microorganisms inspire us to invent new materials and medicines for coping with extreme environments. They also play a part in regulating carbon and oxygen, and the Earth's climate over its long history [3]. Some of the microorganisms produce interesting chemicals, such as methane, which we may use to generate energy.

As the microorganisms are buried, the tremendous amount of seawater and sediments above squeeze their living environment. The deeper the microorganisms are buried, the less water is in their immediate environment (Figure 2b). Thus, while the seafloor is right under seawater, the microorganisms under the seafloor can face a lack of water. 
Figure 2

Changes in physical conditions under the seafloor, measured in the Nankai Trough, east of Japan [2]. (a) At the seafloor $(4.8 \mathrm{~km}$ underwater), the pressure is already high-imagine 305 elephants standing on your chest! When we go down another kilometer under the seafloor, the pressure greatly increases, to an equivalence of about 365 elephants standing on your chest-60 elephants more! (b) Microorganisms live in the space with water between sand and clay grains. At the seafloor, $60 \%$ of the sediment is space. At $1 \mathrm{~km}$ under the seafloor, half of the space that can hold water is gone. (c) The temperature increases from $2^{\circ} \mathrm{C}$ at the seafloor to about $100^{\circ} \mathrm{C}$ at $1 \mathrm{~km}$ below the seafloor. That is the difference between swimming in Arctic water and in boiling water. The deep sediment at the Nankai Trough is particularly hot. Ordinary sediments at $1 \mathrm{~km}$ depth are about $20^{\circ} \mathrm{C}$.

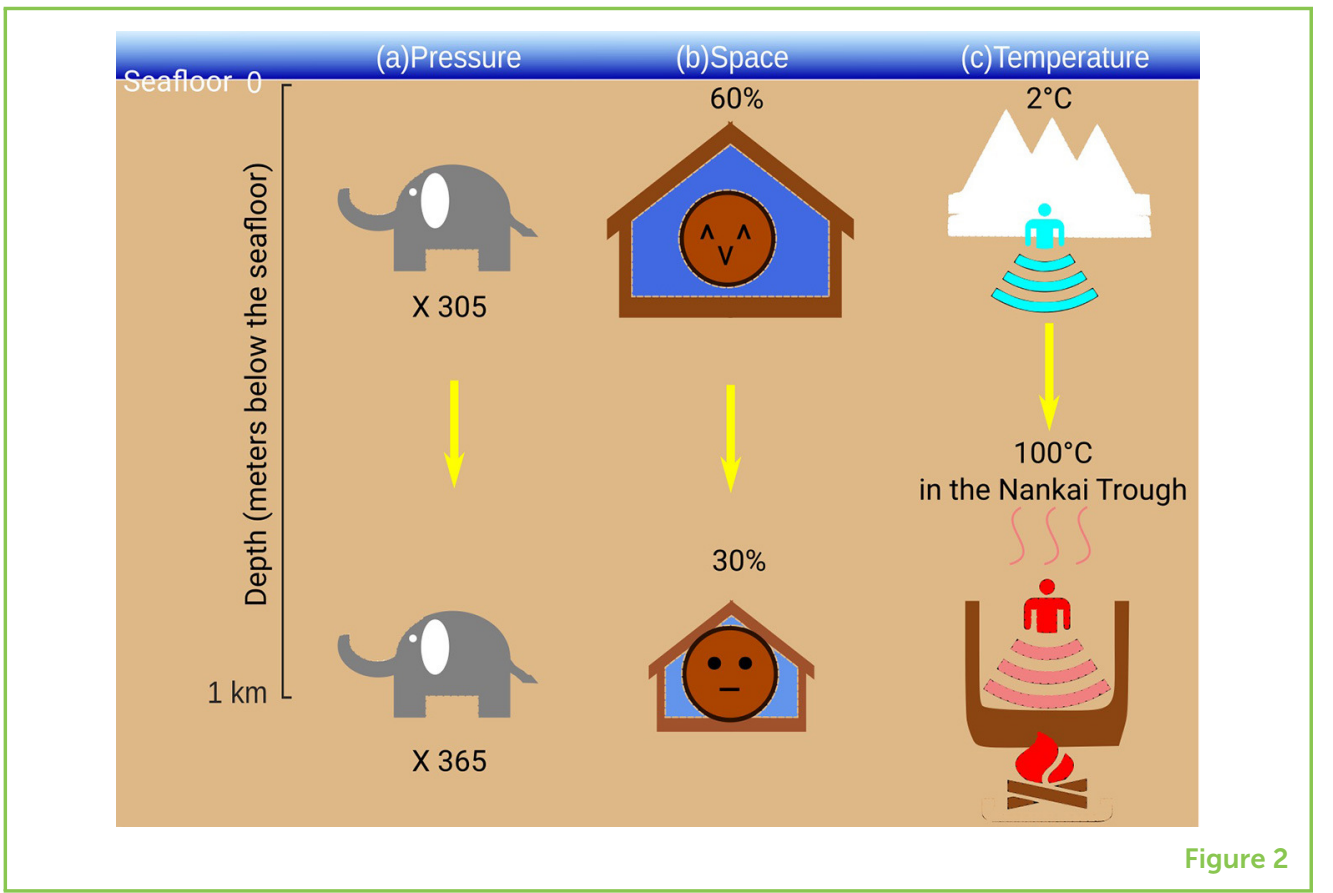

Another challenge to these deep microorganisms is a lack of food. Less than $10 \%$ of the organic food from the sea surface eventually reaches the seafloor [3]. If you have a banana, which part of the banana will you eat, the sweet flesh inside or the tough peel? Most of us will choose the sweet flesh. It is a similar situation in the deep sea. As food sinks from the sea surface, organisms above the seafloor take whatever is easy to digest and yields the most energy. The last bits of food that reach the seafloor are the less favorable options, the "banana peel" left on the plate. Since they have food with very few nutrients, microorganisms deep below the seafloor need to conserve their energy, so they are not very active. They can only afford to expend energy that is essential for survival, for example, to repair body damage and support the basic functions of life.

Since these deep microorganisms are inactive, you may be picturing them "chilling" under the seafloor! But, "chilling" is not exactly the right word, because their homes can be very hot! The deeper the microorganisms, the higher the surrounding temperature (Figure 2c). Why? Well, there is heat coming from inside the Earth. Sediments above the microorganisms are like blankets that trap heat, so the temperature increases. The thicker the blanket, the hotter the environment becomes. The temperature commonly increases by $2^{\circ} \mathrm{C}$ every $100 \mathrm{~m}$ (however, in some areas, such as the Nankai Trough east of Japan, the temperature can increase by $10^{\circ} \mathrm{C}$ every $100 \mathrm{~m}$ ). By volume, half of the marine sediments on Earth have temperatures higher than $40^{\circ} \mathrm{C}$; a quarter are higher than $80^{\circ} \mathrm{C}$ [4].

After learning about all of these challenges, we can conclude that life is difficult under the seafloor. We might think that any organisms would 
Figure 3

(a) The Chikyu, a drilling research vessel. The polygonal platform at the bow is a helicopter deck and the tall tower behind is a drill rig. (b) Part of a sediment drill core (IODP Site C0023

[2]). The circle indicates a greenish-yellow, roughly $5 \mathrm{~cm}$-long, pyrite mineral formed from the waste products of microorganisms. (c) An enlarged image of the pyrite (1,400 times) from a scanning electron microscope [2]. Pyrite under the seafloor is often framboidal (raspberry)-shaped when enlarged.

\section{CONTAMINANT}

A polluting substance that makes samples less pure.

\section{GENETIC MATERIALS}

DNA and RNA. Genetic materials control how the cell develops and behaves. Different types of microorganisms have different genetic materials.

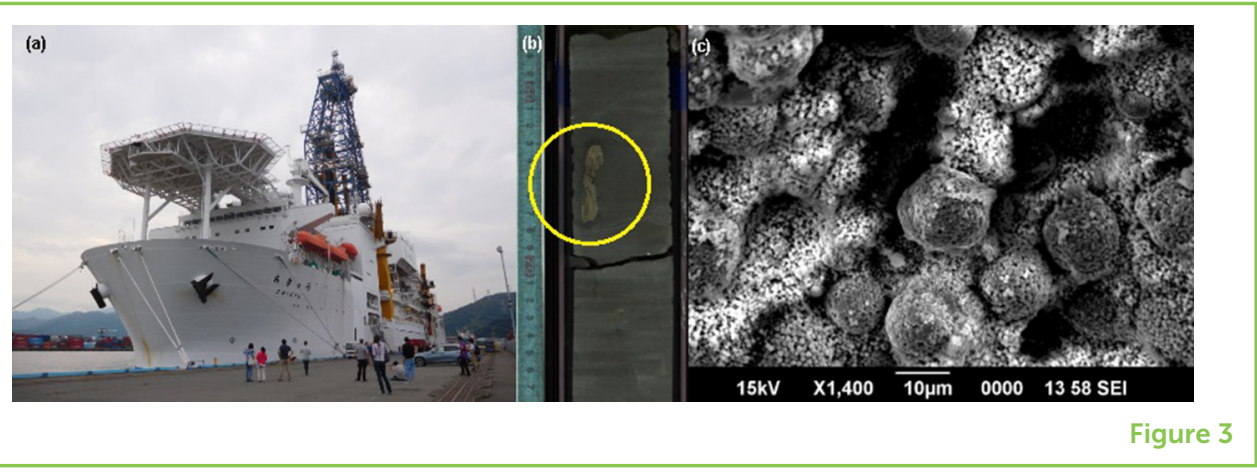

struggle to survive under these conditions, but, to our amazement, we have found living microorganisms with more than $2.5 \mathrm{~km}$ of sediments piled up on top of them! [5]. Laboratory experiments have found that some microorganisms can grow even at $122^{\circ} \mathrm{C}$ [6]. Although they are only performing the basic functions needed for survival, these microbial communities can survive below the seafloor for tens of millions of years. Scientists drill into the seafloor to sample these old microbial communities. Often, when we take these microorganisms back to the laboratory and feed them nutritious food, they thrive again! It is amazing to think about how these tiny organisms have lived in hardship, persisting for millions of years. If, 1 day, they have a chance to rebound, they make the most of that opportunity.

\section{HOW DO SCIENTISTS STUDY MICROORGANISMS BELOW THE SEAFLOOR?}

To study these deeply buried microorganisms, we first need to take samples of the sediment or rock under the seafloor. When studying microorganisms in coastal areas, we can sail a small boat to take samples. In the deep sea, with kilometers of water depth, we need specialized vessels that can drill into the seafloor (Figure 3a).

Once we get the samples, we remove the outer layer of the samples to get rid of contaminants from seawater during drilling. Then we further process the samples to preserve them for later studies. For example, some biological and chemical studies require the samples to remain fresh, so we store them in freezers below $0^{\circ} \mathrm{C}$ or even at $-80^{\circ} \mathrm{C}$. When studying microorganisms that do not like oxygen from the air, we need to process the samples in nitrogen-filled boxes in the laboratory. We clean and sanitize equipment and always wear gloves to prevent contamination of the samples with microorganisms from our own bodies. Some laboratories are even designed to prevent dust in the air from contaminating the samples.

To count the number of microorganisms in each sample, we can look at the samples with high-power microscopes. To learn about who the microorganisms are, we can analyze the genetic materials (DNA or 


\section{SULFATE}

An abundant chemical in seawater. It is made of the elements sulfur and oxygen. Some microorganisms take in sulfate to generate energy
RNA) present in the samples. To study how active the microorganisms are, we feed them some artificially prepared food with chemical tags. Later, we measure the number of chemical tags in the waste products of the microorganisms, to calculate how much food the microorganisms take.

We can also study the activities of the microorganisms by looking at the environmental changes they create in the sediments. For example, a large group of microorganisms under the seafloor breathe in dissolved sulfate instead of oxygen. Where this group of microorganisms is active, we can observe a decreased sulfate content in the water of our samples. This group of microorganisms also produces hydrogen sulfide gas, $\mathrm{H}_{2} \mathrm{~S}$, as waste. $\mathrm{H}_{2} \mathrm{~S}$ reacts with iron in the seafloor and forms the mineral pyrite-a greenish-yellow mineral with the nickname "fool's gold" (Figures 3b,c). By studying the pyrite that arises from microbial processes, we can learn about the microorganisms themselves. The advantage of studying minerals is that minerals can be stable in sediments and rocks for millions of years. Thus, using minerals, we can study the activity of microorganisms that lived in the distant past.

\section{CONCLUSION}

Over the past decades, we learned a lot about deep microbial life below the seafloor, but so many questions remain unanswered. These questions include: what is the maximum depth and age at which these microorganisms can live? What is the maximum temperature and pressure they can bear? Do different types of microorganisms help each other to survive in deep sediments? Are there unknown chemical pathways that the microorganisms use to generate energy? Underneath marine sediments are basement rocks, such as basalt. Are the microorganisms in these rocky environments the same as those in the sediments above? Scientists are eagerly trying to answer these questions. Deep microorganisms have surprised us with their persistence and ability to adapt. These tiny organisms deep under the seafloor teach us big lessons and will continue to surprise us in the future.

\section{ACKNOWLEDGMENTS}

We thank Maris Wicks, Virginia Price, Jasmine Prat, Christy H. T. Tse, the young reviewer, his/her science mentor and the editors for their great comments that make this article more interesting and informative to young readers. We also thank Bethany Brookshire who told us about Frontiers for Young Minds and gave great tips on writing to young readers. This article is inspired by ComSciCon 2019, the Canada C3 Expedition and the International Ocean Discovery Program (IODP) Expedition 370 with the drilling research vessel 
Chikyu. This is a contribution to Earth 4D Science and Exploration, CIFAR, Canada.

\section{REFERENCES}

1. Kallmeyer, J., Pockalny, R., Adhikari, R. R., Smith, D. C., and D'Hondt, S. 2012. Global distribution of microbial abundance and biomass in subseafloor sediment. Proc. Natl. Acad. Sci. U.S.A. 109:16213-6. doi: 10.1073/pnas. 1203849109

2. Heuer, V. B., Inagaki, F., Morono, Y., Kubo, Y., and Maeda, L. 2017. "The Expedition 370 scientists: temperature limit of the deep biosphere off Muroto," in Proceedings of the International Ocean Discovery Program (College Station, TX: International Ocean Discovery Program), 370. doi: 10.14379/iodp.proc.370.2017

3. Bender, M. L., and Heggie, D. T. 1984. Fate of organic carbon reaching the deep sea floor: a status report. Geochim. Cosmochim. Acta 48:977-86. doi: 10.1016/0016-7037(84)90189-3

4. LaRowe, D. E., Burwicz, E., Arndt, S., Dale, A. W., and Amend, J. P. 2017. Temperature and volume of global marine sediments. Geology 45:275-8. doi: $10.1130 / G 38601.1$

5. Inagaki, F., Hinrichs, K. U., Kubo, Y., Bowles, M. W., Heuer, V. B., Hong, W. L., et al. 2015. Exploring deep microbial life in coal-bearing sediment down to $\sim 2.5 \mathrm{~km}$ below the ocean floor. Science 349:420-4. doi: 10.1126/science.aaa6882

6. Takai, K., Nakamura, K., Toki, T., Tsunogai, U., Miyazaki, M., Miyazaki, J., et al. 2008. Cell proliferation at $122^{\circ} \mathrm{C}$ and isotopically heavy $\mathrm{CH}_{4}$ production by a hyperthermophilic methanogen under high-pressure cultivation. Proc. Natl. Acad. Sci. U.S.A. 105:10949-54. doi: 10.1073/pnas.0712334105

SUBMITTED: 31 July 2019; ACCEPTED: 27 April 2020;

PUBLISHED ONLINE: 29 May 2020.

EDITED BY: Gianpiero Vigani, University of Turin, Italy

CITATION: Tsang M-Y and Inagaki F (2020) Microbial Life Deep Under the Seafloor-A Story of Not Giving Up. Front. Young Minds 8:70. doi: 10.3389/frym. 2020.00070

CONFLICT OF INTEREST: The authors declare that the research was conducted in the absence of any commercial or financial relationships that could be construed as a potential conflict of interest.

COPYRIGHT @ 2020 Tsang and Inagaki. This is an open-access article distributed under the terms of the Creative Commons Attribution License (CC BY). The use, distribution or reproduction in other forums is permitted, provided the original author(s) and the copyright owner(s) are credited and that the original publication in this journal is cited, in accordance with accepted academic practice. No use, distribution or reproduction is permitted which does not comply with these terms. 


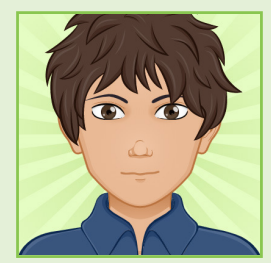

\section{YOUNG REVIEWER}

\section{NICOLAS, AGE: 9}

I grew up in Spain but now I live in Vienna. I can speak in German, English, and Spanish. My favorite subject at school is Maths and my favorite sport is football (soccer for Americans).

\section{AUTHORS}
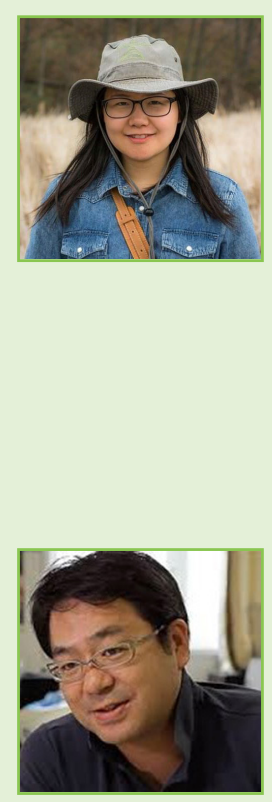

\section{MAN-YIN TSANG}

Man-Yin is a marine geoscientist at the University of Toronto. Her passion is to understand the interactions between microorganisms and the geological environment. She moved from Hong Kong to Toronto to research on this topic. In 2016, she represented Canada as a shipboard geoscientist in Expedition 370 of the International Ocean Discovery Program, the "Temperature Limit of Life off Muroto." Man-Yin and about 30 other scientists from different countries spent 2 months in the Northwestern Pacific Ring of Fire, drilling through $5 \mathrm{~km}$ of seawater and $1.2 \mathrm{~km}$ of sediments to study microorganisms in the deep, hot subseafloor. *my.tsang@amail.utoronto.ca.

\section{FUMIO INAGAKI}

Fumio is a geomicrobiologist and the Director of the Mantle Drilling Promotion Office at the Japan Agency for Marine-Earth Science and Technology (JAMSTEC). He has devoted himself to understanding the deep microbial life in the ocean for 20 years. He led multiple scientific expeditions offshore and innovated techniques to study the microorganisms. Fumio receives the Copernicus Medal, the PNAS Cozzarelli Prize, and the AGU Asahiko Taira International Scientific Ocean Drilling Research Prize for his ground-breaking work. In the coming future, Fumio aims to study more about life and Earth interactions, even between life and the mantle. 